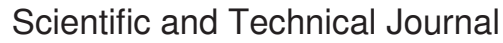 \\ Safety \& Defense 5(2) (2019) 62-67
}

\section{Biological Security of Polish Military Contingents Outside the Country}

\author{
Beata OSIAK \\ Polish Air Force University, Dęblin, Poland; e-mail: b.osiak@law.mil.pl, \\ ORCID: 0000-0001-8323-773X
}

\begin{abstract}
Polish soldiers have been participating in peacekeeping and stabilization missions around the world for several decades under the auspices of the UN, OSCE, NATO and the EU. They were first sent to Korea in 1953 to oversee a ceasefire between the North and South Koreas. Since then, nearly 70,000 Polish troops have taken part in 58 peace and humanitarian multinational missions on different continents (SKMP ONZ, 2019), which required from them great skills to cooperate with soldiers from other countries, to overcome cultural barriers, as well as adaptation to difficult climatic conditions, often completely different than those experienced in Europe, and to create a system of safeguards and procedures against dangerous tropical diseases. As a result, biological safety, i.e., medical, sanitary-hygienic, and anti-epidemic security of the contingent, plays a significant role in every mission because it allows the soldiers and civilian personnel stay healthy in unfavorable and different climatic and environmental conditions.
\end{abstract}

Keywords: biological security, identification of threats, Polish Military Contingent, safety

\section{Introduction}

The 21st century has brought forth a great opportunity to move people over long distances in a short period of time, often by the means of air transport. These destinations are often distant countries and continents with a different climate where one gets exposed to various pathogens which are harmless to natives, but may cause many unpredicted health issues among foreigners. Simply drinking water can become a cause of unpleasant stomach problems. The dangers posed by infections with biological agents like viruses, bacteria, or parasites, are a fundamental problem for biological security of the Polish Military Contingents stationed in various places around the world, today mainly in Asia and Africa. Apart from the health risks and problems caused by active participation in war and stabilization missions (e.g., gunshot wounds), soldiers and civilian personnel are exposed to numerous exotic diseases and the possible use of biological weapons by terrorists (and, if that occurs, the troops should be provided with a secure transfer back to the country). For these purposes, a structure of the mission military health service has been established. Its main goal is to protect and prevent unforeseen health incidents among the soldiers, and it starts already in Poland. Every soldier of the Polish Military Contingent (PMC) is thoroughly examined in terms of their health before leaving the country. Moreover, all of the troops receive a series of vaccinations that are included in the Preventive Vaccination Plan (GIS, 2018) published at the end of each calendar year for the following year and are recommended by the Ministry of Health and Ministry of Foreign Affairs and the Department of Military Health Service. 
The goal of this review paper is to identify and characterize the biological hazards the Polish Military Contingents can be exposed to. Furthermore, legal framework related to this issue is discussed, and safeguards against the possible consequences of the occurrence of such threats are analyzed.

\section{Polish Military Contingents in the Past and Present}

The Polish Military Contingent (PMC) is a separate military unit of the Polish Armed Forces (operational forces) intended to participate in a foreign military operations (peace-keeping, stabilization, or war) in accordance with the decision of the President of the Republic of Poland at the request of the Council of Ministers (Mróz, 2004). This definition sets out that each soldier and civilian personnel member designated for the mission are treated in particular in terms of preparatory training. They all undergo detailed health tests and the entire vaccination cycle necessary to protect the "missionary" against possible infections with tropical or parasitic diseases, which do not commonly occur in Poland.

Polish soldiers have been participating in missions abroad since 1953. The first mission took place in North Korea where the Polish military participated in the Neutral Nations Supervisory Commission (NNSC) as observers overseeing the ceasefire. Three hundred Polish troops were deployed there as well as 60 military doctors who worked at the Polish Red Cross hospital. Later on, the PMC was sent to other destinations, including missions in Indochina in 1954-1976 and Nigeria in 1968-1970 (Krzemińska, 2014). However, the first Polish military contingent operating under the United Nations Emergency Force (UNEF) - Polish Special Military Unit (PMSU) was sent to Syria as part of the so-called "blue helmets" in 1973-1979. The name "Polish Military Contingent" was officially used for the first time in 1979. Since then, Polish soldiers have been involved in numerous missions: since 1992 as PMC in Croatia; in 1996, Polish military units were sent to Bosnia and Herzegovina, Albania, and Kosovo as NATO support (since 2000, these units have been called Polish Military Contingents). After this period, the largest contingents were deployed, i.e., PMC Afghanistan and PMC Iraq, within the North Atlantic Treaty Organization. During these missions, 2,600 Polish troops were deployed in one turn. Until recently, Polish soldiers also participated in international peacekeeping operations and stabilization missions in Congo, Chad and Lebanon. (Pawłowski, 2010). The deployment of the Polish troops in Asia and Africa is shown in Map 1; and Map 2 depicts the presence of the PMC in Europe.

Since 2003, Polish soldiers have served in Bosnia and Herzegovina as part of the European Union peacekeeping forces, and since 2006, the Military Gendarmerie has played a special role. The PMC also operated as part of ad hoc multinational coalitions, e.g., in 1985-1987, the Polish Relief Helicopter Squadron served in Ethiopia during the Tesfa humanitarian operation. The following years brought two wars in the Persian Gulf in Iraq, where Polish soldiers played a significant role in the stabilization of the region. It was the second largest Polish Military Contingent in history - about two and a half thousand soldiers were deployed in one turn.

Since 2009, Poland has significantly reduced its presence in the United Nations peacekeeping forces by withdrawing all military contingents, and since 2014, i.e., the completion of International Security Assistance Force (ISAF) missions, the PMC have been mainly involved in training and patrol activities (Smolarek, 2016).

Map 1. Polish Military Contingents in Asia and Africa (as of July 13, 2017)

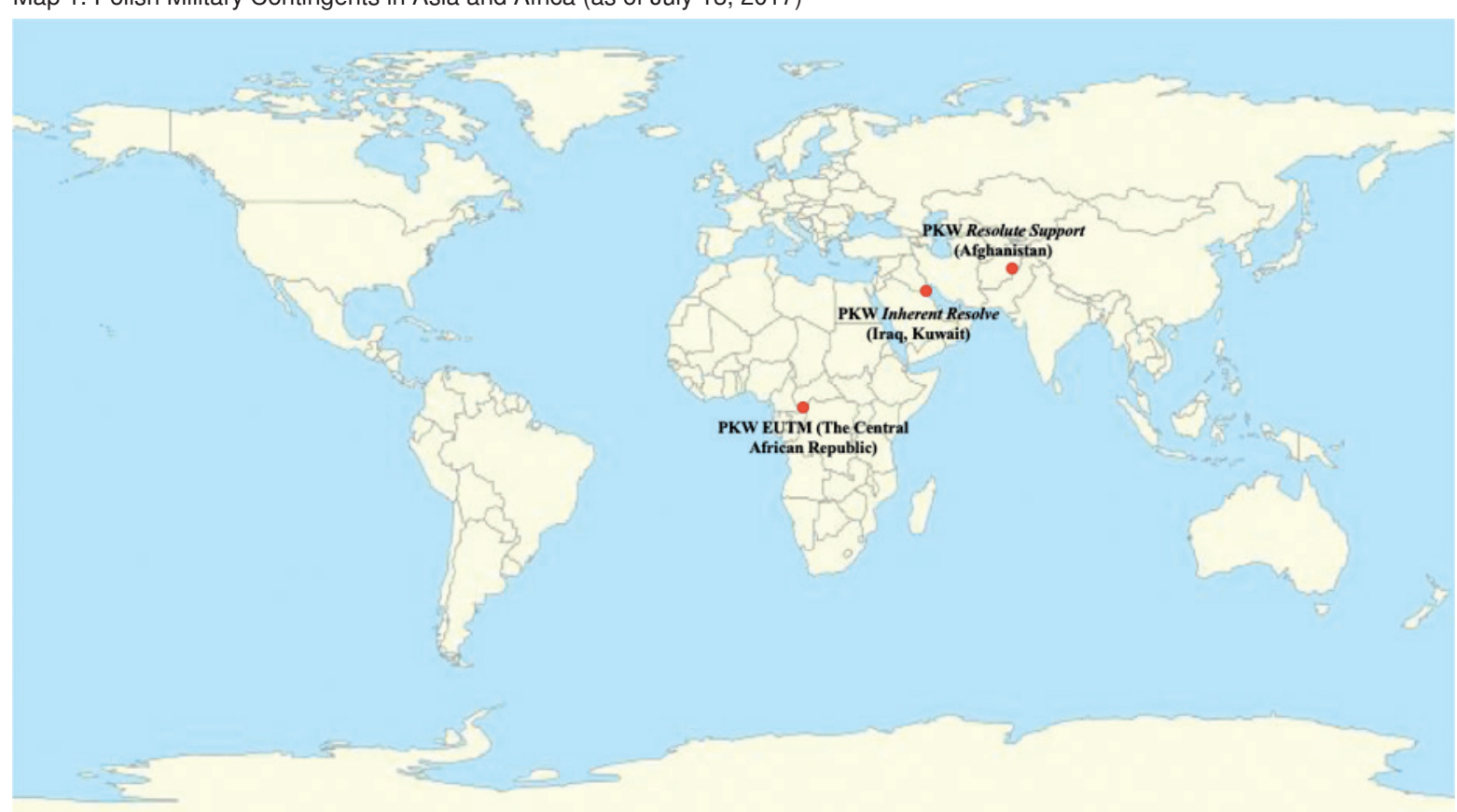

On the basis of: https://pl.wikipedia.org/wiki/Polski_kontyngent_wojskowy; 03.11.2019. 


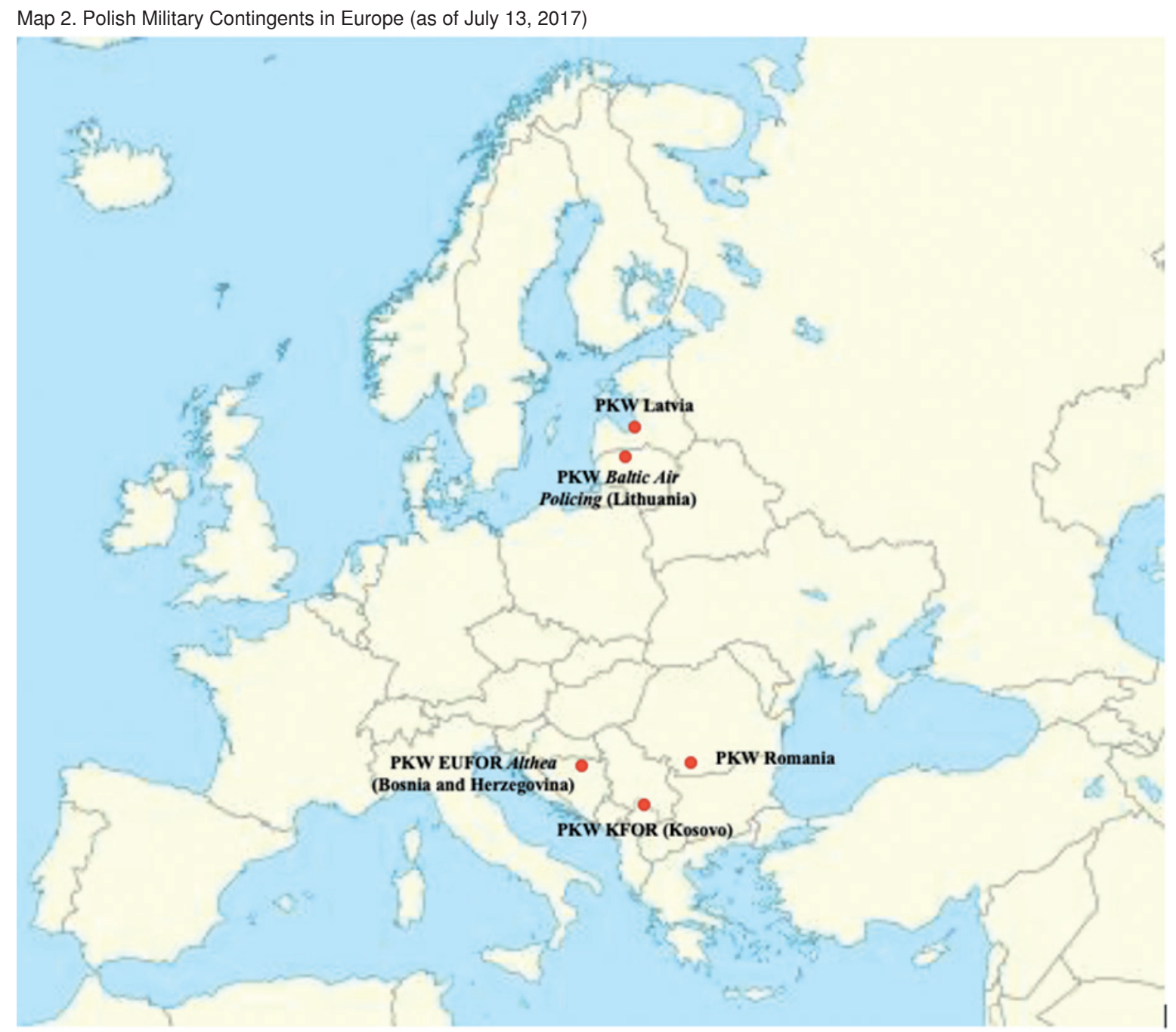

On the basis of: https://pl.wikipedia.org/wiki/Polski_kontyngent_wojskowy; 03.11.2019.

\section{Biological Safety of the Polish Military Contingent}

The American Center for Disease Control and Prevention (CDC) defines biological safety or biosafety as "the discipline addressing the safe handling and containment of infectious microorganisms and hazardous biological materials" (CDC, 2016). In other words, biosecurity includes, i.a., undertaking measures to reduce public health risks by controlling and eliminating pathogenic factors such as viruses, bacteria, fungi, toxins or other microorganisms commonly found in nature.

Biological safety is an essential element of the proper functioning of soldiers, not only in their home country but, above all, during international missions. One of the most important Polish documents governing the procedures for dealing with the emergency caused by biological, often pathogenic, factors, is the Ministry of National Defense Decision No. 53/MON issued on March 5, 2013, which introduces instructions on sanitary and anti-epidemic protection of the military during peace, crisis and war (MON, 2013). It clearly lays down the principles of protecting the health of troops and supervising the health risks of soldiers and civilian personnel outside the country during ongoing peacekeeping and stabilization missions. Detailed operational procedures for foreign missions are described in the NATO standardization documents (Kucharek, 2017), i.e., AJMedP-4 - Allied Joint Medical Force Health Protection Doctrine (NATO, 2018) and AMedP-4.1 - Deployment Health Surveillance (NATO, 2017).

The aforementioned sanitary-hygienic and epidemiological documents accurately clarify the health risks of soldiers on foreign missions, among which there are pathogenic factors, and related diseases that occur mainly where there is a low level of hygiene, poverty and armed conflicts. Other threats include environmental contamination in low-industrialized areas of the world and the deliberate use of weapons of mass destruction (WMD), including biological weapons.

Military missions involving Polish soldiers and civilian personnel in African and Asian countries pose a very serious threat to the infestation of pathogenic biological agents. This is related to the nature of the activities carried out in politically hostile, military, and most importantly, potentially epidemiological areas by the troops. Such situations involve economic, social, and political destabilization. Proper infrastructure is destroyed by the ongoing conflict. The acquisition of water 
often becomes very difficult, sometimes even impossible. All-present famine causes a decrease in immunity, and consequently, the spread of infectious diseases, which poses a serious threat to the health and life of soldiers stationed in these areas. The drastic epidemiological situation is exacerbated by climate conditions, e.g., high temperature leads to the development of infectious and parasitic diseases. Such conditions encourage the development of respiratory

Fig. 1. Organizational Structure of the Health Service of Polish Military Contingent in Syria (UNDOF)

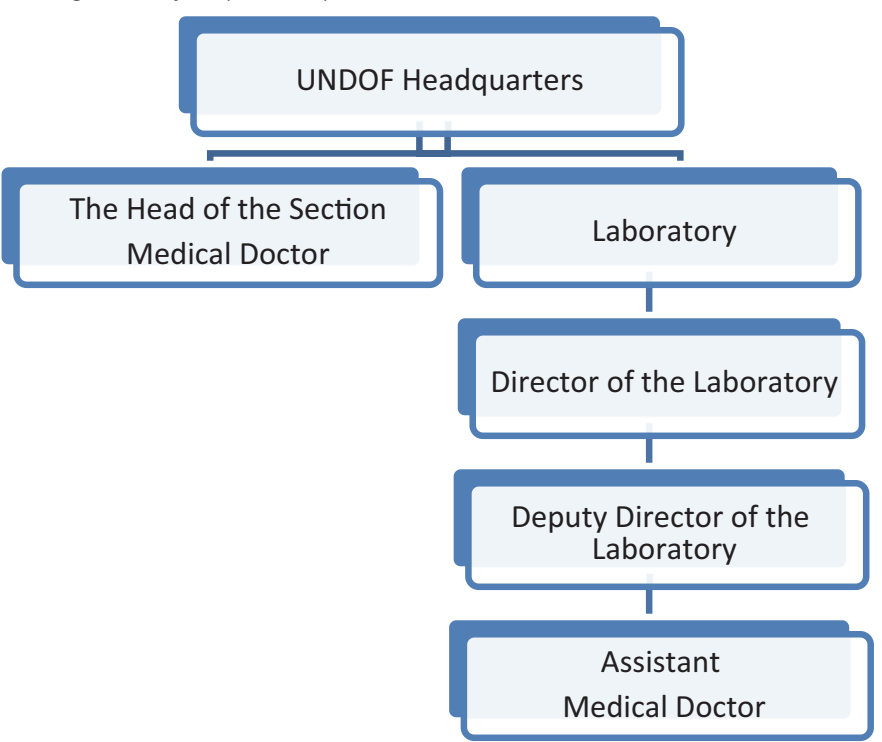

diseases, while low hygiene standards largely contribute to the spread of diseases transmitted by food, zoonoses and transmission diseases (Korzeniewski, Smoleń, 2015).

A soldier's health and life can also be threatened while on a mission by potential deliberate use of biological weapons (BW), commonly known as bioterrorism that can be defined as "is the intentional release of viruses, bacteria, or other germs that can sicken or kill people, livestock, or crops" (CDC, 2018). In other words, it can be understood as an unlawful, illegal use of biological factors such as bacteria, enzymes, parasites, toxins, viruses and other materials of biological origin against humans, plants or animals with the intention of intimidating or forcing a specific action of the government or civilian population to achieve personal, political or social goals (MON, 2013). Soldiers on missions are particularly vulnerable to terrorist groups who can use that type of weapons against them. It is particularly justified due to the fact that, in the base, there are many people in one place, and when the soldiers operate outside of the base, they move in a column, what increases the possibility of transferring the biological factor to the base.

\section{The Organizational Structure of the Polish Military Contingent Health Services}

The Ministry of National Defense and the relevant structures controlling the medical aspect of the Polish Army, i.e., the Department of Military Health Service (earlier the

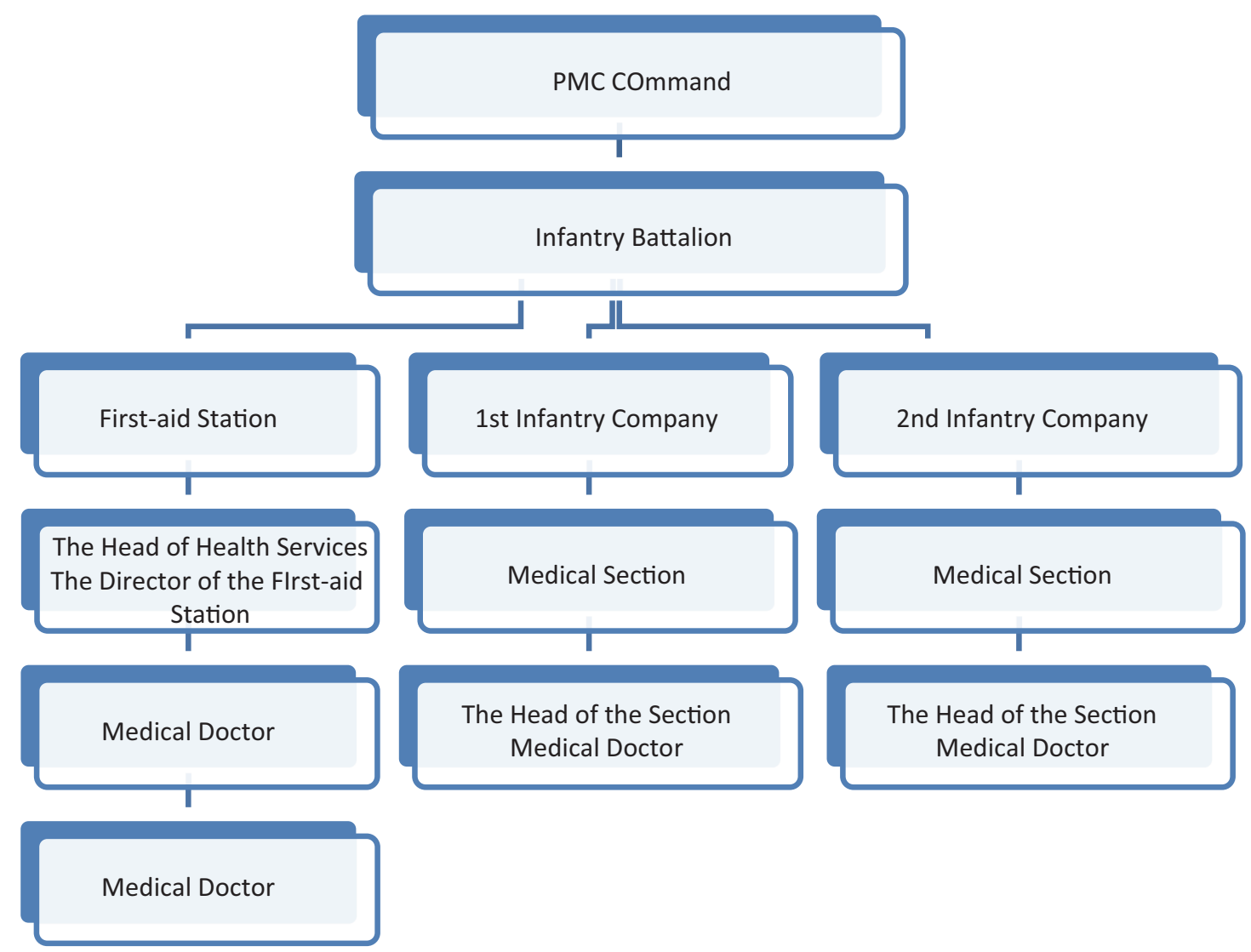

Source: Korzeniowski et al., 2009, p. 153. 
Inspectorate of Military Health Service) have created a comprehensive organizational structure of health service for missions outside the country. The health service of Multinational Division Center South (MND CS) in Iraq can serve as a great example, because it was led by the head of health services who was also a medical officer of the PMC. He reported directly to the chief of staff of the division, and was an adviser to that commander with regards to medical, sanitary-hygienic, anti-epidemic security, as well as medical supplies. At the same time, he cooperated with the health services of the other three stabilization zones and with the Iraqi health service. The Polish Military Contingent had a field hospital, which was given to the Polish Armed Forces in 1992 by Sweden, an out-patients' clinic, and an analytical and microbiological laboratory. The hospital actively participated in the medical evacuation of the victims during convoys or fighting outside the base. Figure 1 shows how complex the organizational structure of the health service on the mission in Syria (UNDOF) was. The structure of the health service during the Lebanon mission (UNIFIL) was much smaller, as depicted in Figure 2. The complexity of the structure depended on the position of the PMC in the Multinational Division and on the number of soldiers deployed.

Another important person in securing PMC was the Force Hygiene Officer who was responsible for sanitary and hygienic and anti-epidemic protection of the MND CS units. Among his most important responsibilities there were:

- controlling food and nutrition (important health aspect);

- supervising water testing and determining its suitability for consumption;

- supervising bacteriological and parasitological feces;

- controlling means for disinfection, disinfection and deratization;

- implementing measures to prevent infectious and parasitic diseases, especially food poisoning;

- controlling of the disposal of wastewater and biologically contaminated material;

- carrying out epidemiological investigations in the event of infectious diseases;

- preparing information together with the staff of the Mobile Biological Laboratory on the possibility of using biological weapons and many other tasks related to the health risks of PMC soldiers (Korzeniowski, 2004).

\section{Conclusions}

The service of the soldiers of the Polish armed forces in peacekeeping and stabilization missions in various parts of the world, especially on the African and Asian continents, carries a huge risk of being infected with biological agents causing infectious and parasitic diseases. A different climate, associated with tropical weather, diseases that endemically do not occur in Poland, stress caused by service, a different diet and a number of other factors contribute to both soldiers and civilian personnel being exposed to many health threats. Therefore, the skilled medical personnel exercise protection over the troops having at their disposal a field hospital, an out-patients' clinic, diagnostic and microbiological laboratory and well-prepared procedures for the case of a tropical disease causing not only respiratory, digestive, but also skin complications. The rapid response of medical services will prevent the spread of the disease, which can lead not only to serious complications, but even death, e.g., hemorrhagic fevers caused by the Ebola virus, Dengue or Nipa.

The organizational structure of the health service on missions is supervised directly by the Department of Health Services in Poland, which delegates qualified and trained medical personnel for such tasks. Sanitary and anti-epidemic 
aspects are clearly defined by the instruction on sanitary and anti-epidemic security of the army during times of peace, crisis and war [Instrukcja o zabezpieczeniu sanitarnohigienicznym i przeciwepidemicznym wojska w czasie pokoju, kryzysu i wojny] (MON, 2013), which is a master document for the Polish Army, and the extensive experience of the medical personnel on missions has contributed to creating this manual and hence eliminate many threats.

\section{References}

[1] CDC [Center for Disease Control and Prevention] (2018). Bioterrorism, 10.09. 2018, https://www.cdc.gov/anthrax/bioterrorism/index. $\mathrm{html}(04.11 .2019)$.

[2] CDC [Center for Disease Control and Prevention]. (2016). Bloodborne Infectious Diseases: Hiv/Aids, Hepatitis B, Hepatitis: General Resources on Bloodborne Pathogens, 05.10.2016., https://www. cdc.gov/niosh/topics/bbp/genres.html (07.11.2019).

[3] GIS [Główny Inspektor Sanitarny]. (2018). Komunikat Głównego Inspektora Sanitarnego w sprawie Programu Szczepień Ochronnych na rok 2019 r., Dziennik Urzędowy Ministra Zdrowia, 25.10.2018, http://dziennikmz.mz.gov.pl/\#/search?year=2018\&publisherld=4\&timeStamp=1540477314254 (10.11.2019).

[4] Korzeniewski, K. (2004). "Zadania i struktura organizacyjna służby zdrowia Wielonarodowej Dywizji Sił Stabilizacyjnych w Strefie Środkowo-Południowej w Iraku," Lekarz Wojskowy 80(3): 211-214.

[5] Korzeniewski, K., Smoleń, A. (2015). Problemy zdrowotne żołnierzy Polskich Kontyngentów Wojskowych - choroby z importu. Współczesne zagrożenia cyberterrorystyczne i bioterrorystyczne a bezpieczeństwo narodowe Polski. Warszawa-Dęblin: Wydawnictwo Wyższej Szkoły Policyjnej w Szczytnie.

[6] Korzeniowski, K., et al. (2009). "Udział żołnierzy Wojska Polskiego w operacjach poza granicami państwa," Lekarz Wojskowy 87 (3): $151-159$
[7] Krzemińska, A. (2014). „Ocena dotychczasowego funkcjonowania systemu opieki nad żołnierzami Polskich Kontyngentów Wojskowych i ich rodzin," Obronność. Zeszyty Naukowe 3(11): 35-53.

[8] Kucharek, D. (2017). "Procedury sanitarne żołnierzy wracających z misji wojskowych poza granicami kraju," Wybrane aspekty zastosowania bojowego lotnictwa, Dęblin: WSOSP.

[9] MON[MinisterstwoObrony Narodowej].(2013).Instrukcjaozabezpieczeniu sanitarnohigienicznym i przeciwepidemicznym wojska w czasie pokoju, kryzysu i wojny, 05.03.2013, http://www.dz.urz.mon.gov. $\mathrm{pl} /$ dziennik/pozycja/decyzja-62-decyzja-nr-53mon-z-dnia-5-marca-2013-r-w-sprawie-wprowadzenia-do-uzytku-instrukcji-o-zabezpieczeniu-sanitarnohigienicznym-i-przeciwepidemic/ (29.10.2019).

[10] Mróz, Marcin. (2004). "Podstawy prawne obecności polskiego kontyngentu wojskowego w Iraku," Kancelaria Sejmu, Biuro Studiów i Ekspertyz, październik 2004, Informacja Nr 1069, http://biurose. sejm.gov.pl/teksty_pdf_04/i-1069.pdf (08.11.2019).

[11] Pawłowski, Konrad. (2010). „Misje pokojowe i operacje stabilizacyjne Sił Zbrojnych Rzeczpospolitej Polskiej na początku XXI wieku: przesłanki i głosy krytyczne," Teka Komisji Politologii i Stosunków Międzynarodowych - O.L. PAN: 94-107.

[12] NATO [The North Atlantic Treaty Organization] (2017). NATO Standard AMedP-4.1 - Deployment Health Surveillance. Edition A Version 2, January 2017. NATO Standardization Office, https:// www.coemed.org/files/stanags/03_AMEDP/AMedP-4.1_EDA_ V2_E_2535.pdf (29.10.2019).

[13] NATO [The North Atlantic Treaty Organization]. (2018). NATO Standard AMedP-4 - Allied Joint Medical Force Health Protection Doctrine, Edition A Version 1, July 2018. NATO Standardization Office, https://www.coemed.org/files/stanags/02_AJMEDP/ AJMedP-4_EDA_V1_E_2561.pdf (29.10.2019).

[14] SKMP ONZ [Stowarzyszenie Kombatantów Misji Pokojowych ONZ]. (2019). Misje pokojowe Polaków, http://skmponz.pl/misje-pokojowe-polakow-1953-2010/ (11.11.2019).

[15] Smolarek, Mirosław (2016). „Udział Wojska Polskiego w operacjach pokojowych na Bałkanach," Międzynarodowe operacje pokojowei stabilizacyjne w polskiej polityce bezpieczeństwa w XX i XXI wieku. AON: 116-136. 